\title{
Mucosal Macrophages in Intestinal Homeostasis and Inflammation
}

\author{
Allan Mcl Mowat Calum C. Bain \\ Institute of Infection, Immunology and Inflammation, University of Glasgow, Glasgow, UK
}

\section{Key Words}

Macrophage $\cdot$ Intestine $\cdot$ Inflammation $\cdot$ Homeostasis

\begin{abstract}
Intestinal macrophages are essential for local homeostasis and in keeping a balance between commensal microbiota and the host. However, they also play essential roles in inflammation and protective immunity, when they change from peaceful regulators to powerful aggressors. As a result, activated macrophages are important targets for treatment of inflammatory bowel diseases such as Crohn's disease. Until recently, the complexity and heterogeneity of intestinal macrophages have been underestimated and here we review current evidence that there are distinct populations of resident and inflammatory macrophages in the intestine. We describe the mechanisms that ensure macrophages remain partially inert in the healthy gut and cannot promote inflammation despite constant exposure to bacteria and other stimuli. This may be because the local environment 'conditions' macrophage precursors to become unresponsive after they arrive in the gut. Nevertheless, this permits some active, physiological functions to persist. A new population of proinflammatory macrophages appears in inflammation and we review the evidence that this involves recruitment of a distinct population of fully responsive monocytes, rather than alterations in the existing cells. A constant balance be-
\end{abstract}

tween these resident and inflammatory macrophages is critical for maintaining the status quo in healthy gut and ensuring protective immunity when required.

Copyright $\odot 2011$ S. Karger AG, Basel

\section{Introduction}

Macrophages ( $\mathrm{m} \Phi)$ are one of the most abundant leucocytes in the intestine of all mammalian species and this is probably the largest population of mononuclear phagocytes in the body [1]. МФ are found throughout the intestinal tract of all mammals, both in the mucosa and deeper layers such as the submucosa and muscularis mucosae. However, they are found in greatest numbers in the lamina propria which forms the core of the mucosa underlying the surface epithelium (fig. 1). They are rare in the epithelium itself, although some specialised populations of mononuclear leucocytes may be able to send processes through the epithelium from the lamina propria to sample luminal contents (see below). Although few detailed studies have been conducted, mucosal $\mathrm{m} \Phi$ numbers in different parts of the intestine appear to correlate closely with the relative bacterial load and thus are highest in the colon, where the number of commensal bacteria is in excess of $10^{12}$ organisms $/ \mathrm{ml}$ [2]. Their numbers are also decreased in the intestine of germ-free mice [3]. Interest-

\section{KARGER}

(C) 2011 S. Karger AG, Basel

Fax +4161306 1234

E-Mail karger@karger.ch

www.karger.com
Dr. Allan McI Mowat

Institute of Infection, Immunology and Inflammation, University of Glasgow

Sir Graeme Davies Building, 120 University Place

Glasgow G12 8TA (UK)

Tel. +44 141330 8414, E-Mail Allan.Mowat@glasgow.ac.uk 
Fig. 1. Location and morphology of $\mathrm{m} \Phi$ in healthy colon. a F4/80+ cells in control mouse colon and 3, 6 and 8 days after induction of DSS colitis, showing the presence of $\mathrm{m} \Phi$ in healthy intestine and the intense infiltrate in inflammation. Reproduced with permission from Stevceva et al. [109]. b Purified F4/80+ class II MHC+ $\mathrm{m} \Phi$ from normal mouse colon show the morphological appearances of activation, with abundant foamy cytoplasmic granules and they phagcoytose FITC-labelled zymosan particles.
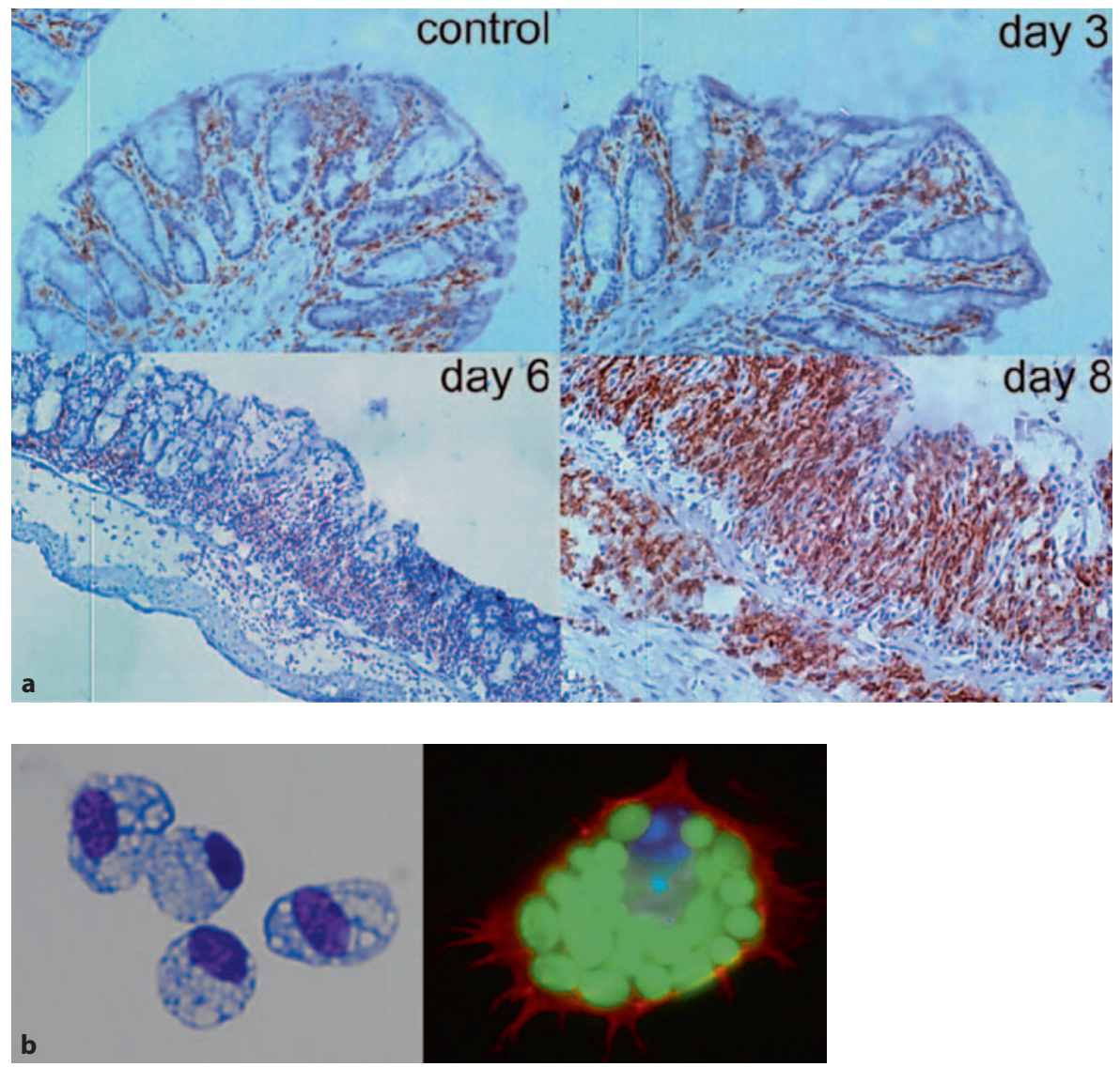

ingly however, $\mathrm{m} \Phi$ are also frequent in more proximal regions of the intestine where bacteria are rare, such as the small intestine.

The intestine is exposed continuously to enormous amounts of antigens, some of which are potentially dangerous pathogens. As prominent effector cells of both innate and adaptive immune responses, $\mathrm{m} \Phi$ would be expected to play important roles in protective immunity against such agents. Similar effector functions are engaged during inappropriate inflammatory responses against harmless local antigens, such as those seen in inflammatory bowel diseases (IBD) and activated $\mathrm{m} \Phi$ are central to the pathogenesis of these disorders. Given that IBD is believed to be driven by the commensal microbiota that are present in large quantities in the normal large intestine and that $\mathrm{m} \Phi$ are also always there, it is intriguing to consider why the intestine is not in a permanent state of inflammation. As we will discuss, this reflects a state of inertia in the resident $\mathrm{m} \Phi$ in the normal intestine that allows these cells to play active and essential roles in maintaining epithelial integrity and mucosal homeosta- sis. In this review, we will discuss the current knowledge of $m \Phi$ in the intestinal mucosa, highlight their phenotypic and functional heterogeneity and discuss how they may be able to play such opposing roles in healthy and inflamed gut.

\section{How to Recognise a Mucosal MФ}

Mucosal $\mathrm{m} \Phi$ show the morphological features of tissue resident $m \Phi$, with a classical mononuclear shape and abundant, granular cytoplasm consistent with active phagocytic behaviour (fig. 1). In man they express the tissue $\mathrm{m} \Phi$ marker macrosialin (CD68) and this is also present on most intestinal $\mathrm{m} \Phi$ in mice (fig. 2) [3], together with the pan-m $\Phi$ markers F4/80, CD11b and the CSF-1 (M-CSF) receptor (CSF-1R; CD115) (table 1) [4-10]. Until very recently, studies of mouse mucosal $\mathrm{m} \Phi$ have been complicated by the imprecise use of these and other markers to identify and purify them. Thus, relatively large numbers of CD11b+F4/80+ eosinophils are present 
Fig. 2. Phenotypic features of resident $m \Phi$ in healthy mouse colon. Two major populations of $\mathrm{F} 4 / 80^{+}$cells are present in populations of live CD45+ cells isolated by enzymatic digestion of mouse colon. The F4/80 ${ }^{\text {hi }}$ class II $\mathrm{MHC}^{\text {hi }}$ cells are $\mathrm{m} \Phi$, as assessed by FSC, SSC and expression of CD68. Unlike resident $\mathrm{m} \Phi$ in other tissues, they also express very high levels of CX3CR1 and significant amounts of CD11c. The cells that express lower levels of F4/80 are class II MHC- and Siglec F+. They also have high SSC and are eosinophils.

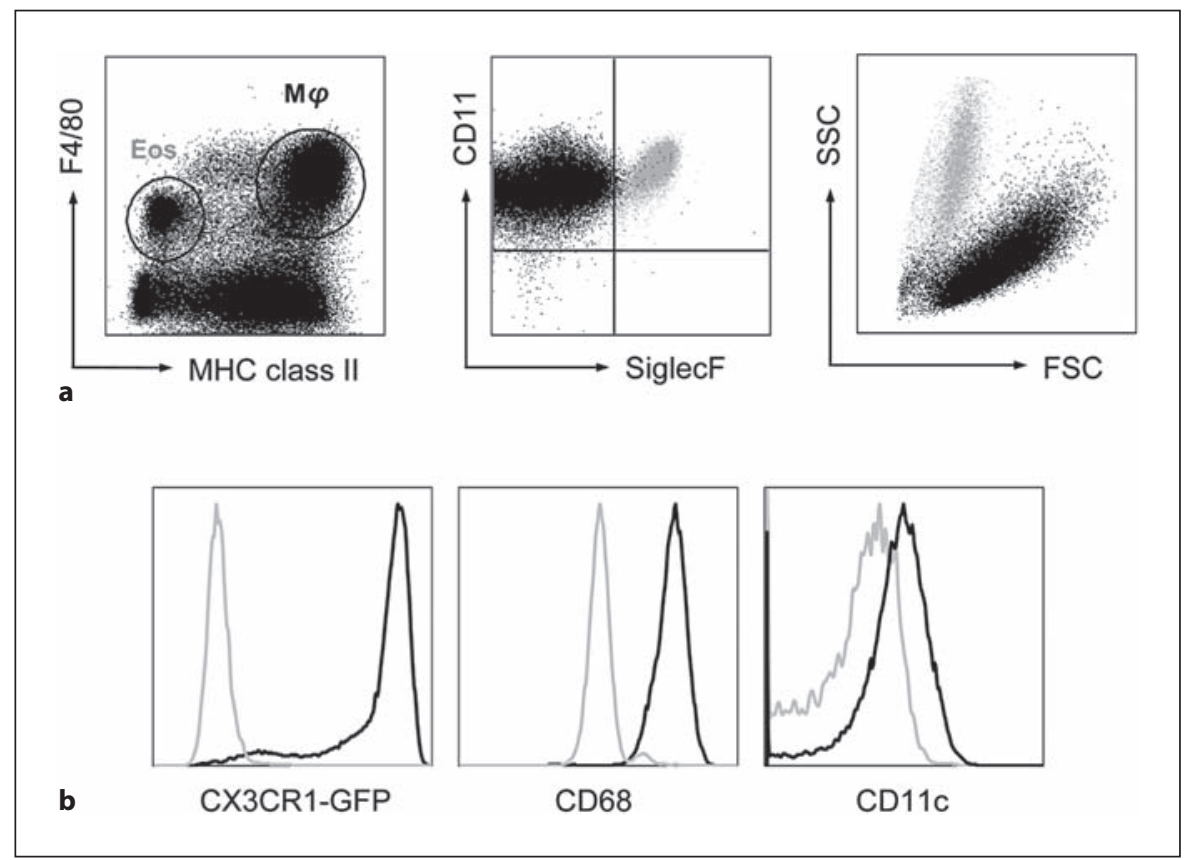

in the normal mouse mucosa and it is necessary to discriminate these directly from $\mathrm{m} \Phi$ on the basis of high SSC and selective expression of Siglec F by eosinophils (fig. 2). An even greater source of inaccuracy has been the assumption that the expression of class II MHC and CD11c allows dendritic cells (DC) to be distinguished from $\mathrm{m} \Phi$ in mouse intestine. In our hands, mature resident $\mathrm{m} \Phi$ from healthy mouse colon uniformly and constitutively express high levels of class II MHC (fig. 2) and human intestinal $\mathrm{m} \Phi$ have also been reported to be class II MHC positive [10]. CD11c expression is also frequently used as a specific marker of murine DC, but well-defined intestinal $\mathrm{m} \Phi$ can express substantial amounts of CD11c (table 1; fig. 2) [7, 9, 11-14].

These findings are compatible with the recent controversies over the relationship between different subsets of mononuclear phagocyte in mice, especially in non-lymphoid tissues, where the distinction between DC and $\mathrm{m} \Phi$ is not as clear as in lymphoid organs $[12,15]$. Importantly, recent studies have shown that many of the mucosal cells identified previously as DC on the basis of being $\mathrm{CD} 11 \mathrm{c}+$ class II MHC+ do not have the functions of classical mucosal DC [14]. Two major phenotypic populations of mucosal mononuclear phagocyte have now been proposed on the basis of expression of CD103 $\left(\alpha_{E} \beta_{7}\right.$ integrin) and CX3CR1, the receptor for the chemokine fractalkine (FKN - CX3CL1) [for review, see 7, 16]. Although both populations express CD11c and class II MHC, only the CD103+ CX3CR1- cells possess the features of classical DC, presenting antigen to naïve $\mathrm{T}$ cells, migrating to MLN and imprinting gut homing markers and FoxP3 expression in naïve $\mathrm{T}$ cells via the production of retinoic acid (RA). Although some of these DC express the myeloid marker CD11b, they are F4/80- CD68-. Conversely, CX3CR1+ cells in the mucosa are CD103-, but are F4/80+ $\mathrm{CD} 11 \mathrm{~b}+\mathrm{CD} 68+$ and do not migrate to MLN or prime naïve T cells, suggesting they are likely to be $m \Phi$ rather than DC. On these grounds, we would suggest that a consensus phenotype for $\mathrm{m} \Phi$ in resting gut is $\mathrm{F} 4 / 80+\mathrm{CD} 11 \mathrm{~b}+$ CX3CR1+ CD103 - class II MHC+ Siglec F- (fig. 2). It remains to be determined whether the same dichotomy applies in other species. Unfortunately, many of the studies discussed below did not use the multiparameter analyses that allow these subsets of mucosal mononuclear cells to be defined precisely and so must be interpreted with appropriate caution.

\section{Functions of Resident Intestinal MФ}

In keeping with their activated appearance and expression of class II MHC, resident intestinal $\mathrm{m} \Phi$ are highly phagocytic (fig. 1) and they express CD36, a receptor that allows phagocytic uptake of apoptotic cells [17]. 
Table 1. Phenotypic comparison of murine $\mathrm{m} \Phi$ populations

\begin{tabular}{|c|c|c|c|c|c|c|}
\hline Marker & $\begin{array}{l}\text { Resident } \\
\text { mucosal } \mathrm{m} \Phi\end{array}$ & $\begin{array}{l}\text { Inflammatory } \\
\text { mucosal } \mathrm{m} \Phi\end{array}$ & Monocyte & M1 mФ & M2 mФ & M2-like TAM \\
\hline CD11b & +++ & +++ & +++ & +++ & +++ & +++ \\
\hline $\mathrm{F} 4 / 80$ & +++ & ++ & $+/-$ & +++ & +++ & $++/+++$ \\
\hline CD68 & ++ & ++ & - & ++ & ++ & ++ \\
\hline Class II MHC & +++ & $++/+$ & - & ++ & + & ++ \\
\hline CD11c & ++ & ++ & - & ++ & - & $+?$ \\
\hline CX3CR1 & +++ & ++ & $-/++^{1}$ & - & - & ++ \\
\hline CCR2 & ++ & +++ & $++/-^{1}$ & ++ & $?$ & + \\
\hline Ly6C & - & $++\rightarrow-$ & $++/-^{1}$ & - & - & - \\
\hline CD40 & $+1-$ & $+/-$ & - & ++ & - & + \\
\hline CD80, CD86 & $+/-$ & $+/-$ & - & ++ & - & + \\
\hline CD14 & ++ & ++ & ++ & ++ & $?$ & $?$ \\
\hline TLR2 & ++ & ++ & +++ & ++ & ++ & \\
\hline TLR4 & $+/-$ & + & +++ & ++ & & \\
\hline MannoseR & $?$ & $?$ & - & - & + & ++ \\
\hline ScavengerR & $?$ & $?$ & - & - & + & ++ \\
\hline Phagocytosis & +++ & +++ & + & +++ & $+/-$ & ++ \\
\hline iNOS & - & ++ & + & +++ & - & - \\
\hline ROI & - & ++ & + & +++ & - & - \\
\hline TNF- $\alpha$ & \pm & +++ & + & +++ & - & + \\
\hline IL-10 & ++ & \pm & - & - & ++ & ++ \\
\hline Arginase & - & $-1++^{2}$ & - & - & ++ & + \\
\hline COX-2 & ++ & $?$ & - & ++ & $+/-$ & ++ \\
\hline IL-4R & - & - & - & - & ++ & - \\
\hline IL-10R & + & - & - & - & - & ++ \\
\hline
\end{tabular}

Resident mucosal $\mathrm{m} \Phi$ in resting mouse intestine are compared with the $\mathrm{m} \Phi$ which infiltrate during intestinal inflammation, blood monocytes and the defined populations of polarised $\mathrm{m} \Phi$ that have been described in mice: M1 ('classical' activated), M2 ('alternative' activated) and M2-like (tumour associated - TAM). $?=$ Not known.

${ }^{1}$ Two subsets of monocytes are described: 'resident' CX3CR1+ Ly6C ${ }^{\text {lo }} \mathrm{CCR} 2^{\text {lo }}$ vs. 'inflammatory' CX 3 CR $1^{\text {lo }}$ Ly6Chi CCR2 ${ }^{\text {hi }}$

${ }^{2}$ A population of arginase-expressing mucosal $\mathrm{m} \Phi$ is found in intestinal helminth infection.

They have also been reported to have strong bactericidal activity [10]. However, they do not express high levels of co-stimulatory molecules such as CD80, CD86 or CD40 $[4,10,11,18,19]$. Most significantly, unlike $m \Phi$ from other tissues, mucosal $\mathrm{m} \Phi$ do not respond to stimuli such as TLR ligands by producing pro-inflammatory cytokines or chemokines such as IL-12, IL-23, TNF- $\alpha$, IL-1, IL-6 or CXCL10 (IP-10) nor do they up-regulate co-stimulatory molecules or generate a significant respiratory burst and nitric oxide production under these conditions $[5,8,10$, 20-23]. Conversely, they produce the anti-inflammatory cytokine IL-10 constitutively or in response to TLR ligation $[5,13,24-26]$. While paradoxical at face value, this split personality is of considerable physiological importance, as ingestion and killing of microbes without initi- ating overt inflammation would allow local $\mathrm{m} \Phi$ to act as a firewall against any commensal bacteria that have crossed the overlying epithelial barrier. In this respect, it now appears that $\mathrm{m} \Phi$ are the CX3CR $1+$ mononuclear phagocytes in the small intestinal lamina propria that may send processes through the epithelium to capture bacteria in the lumen $[7,14,16]$. Originally thought to be DC, these cells have never been shown to present the captured antigen to T cells. However, this luminal sampling appears to be required for the uptake and $\mathrm{T}$ cell recognition of non-pathogenic Salmonella organisms and soluble proteins $[14,27,28]$. The role of these CX3CR1+ $\mathrm{m} \Phi$ may therefore be to pass the material on to DC for transport to the MLN. Alternatively, $\mathrm{m} \Phi$ may degrade their captured contents in a non-inflammatory manner as dis- 
cussed above, or may migrate into the lumen itself in a Myd88-dependent manner, providing a layer of cellular innate defence [29].

\section{MФ Handling of Intestinal Bacteria and Disease Susceptibility}

The ability of intestinal $\mathrm{m} \Phi$ to deal with local commensal bacteria in an appropriate manner is essential for homeostasis, as genes that interfere with these processes are associated with susceptibility to IBD in man [30]. Most notable of these is the intracellular pattern recognition receptor NOD-2 present in $\mathrm{m} \Phi$ that recognises muramyl dipeptide in peptidoglycan from bacterial cell walls. Around $30 \%$ of patients with small intestinal Crohn's disease have a non-functional polymorphism in the NOD-2 gene, the strongest genetic linkage yet discovered in human IBD [31, 32]. Knock-out of NOD-2 in experimental animals has rather inconsistent effects, but overall, it is associated with a failure of $m \Phi$ to generate appropriate innate responses to bacteria [31]. Autophagy is a further important mechanism in the control of innate immune responses to intracellular bacteria and viruses, and polymorphism in the autophagy-associated gene Atg16L1 has also been associated with susceptibility to Crohn's disease [33, 34]. Atg16L1 is expressed highly by intestinal epithelial cells and is also functional in $\mathrm{m} \Phi[35$, 36]. The immunity-related GTPase family M (IRGM) protein is also involved in autophagy and innate defence to intracellular organisms and genetic polymorphism in IRGM is linked to Crohn's disease [37, 38]. Together these findings support the view that dysregulated $\mathrm{m} \Phi$ responses to intestinal bacteria are important factors in human IBD.

\section{Anti-Inflammatory Properties of Resident Intestinal MФ}

Resident intestinal $\mathrm{m} \Phi$ do not just contribute to intestinal homeostasis by acting as a waste disposal unit for local bacteria, but also actively regulate epithelial integrity. As a result, depletion of resident $\mathrm{m} \Phi$ increases susceptibility of mice to experimental colitis and acute intestinal graft versus host disease $[9,39,40]$. Among the mechanisms that may account for this trophic effect is cyclo-oxygenase 2-dependent production of prostaglandin $\mathrm{E} 2$ by $\mathrm{m} \Phi$ located in the stem cell niche of the epithelium [41]. Whether this is the only mediator that enables mucosal $\mathrm{m} \Phi$ to regulate epithelial cell renewal and whether $m \Phi$ act directly on epithelial stem cells or via other cell types such as mesenchymal cells remains to be established. Interestingly, cyclo-oxygenase 2 may also contribute to one further active function of intestinal $\mathrm{m} \Phi$, namely their production of the anti-inflammatory cytokine IL-10 [42]. Expression of the transcription factor peroxisome proliferator-activated receptor- $\gamma$ (PPAR- $\gamma$ ) by mucosal $\mathrm{m} \Phi$ is a further mechanism by which resident $\mathrm{m} \Phi$ can prevent local inflammation, via its ability to suppress pro-inflammatory gene expression [43] and by restricting CCR2-dependent entry of pro-inflammatory monocytes into the intestine [44].

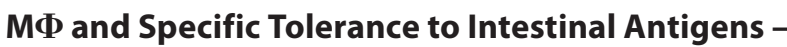 An Unexpected Alliance?}

Recently, an additional and somewhat surprising physiological role for intestinal $\mathrm{m} \Phi$ has emerged, namely in regulating antigen-specific tolerance. This was first suggested by evidence that F4/80 KO mice did not develop tolerance or antigen-specific CD8+ regulatory $\mathrm{T}$ cells (Treg) normally after feeding soluble antigen, but the cellular and anatomical processes underlying this defect were not determined [45]. CD11b KO mice also have a defect in oral tolerance, but this could reflect the absence of either $m \Phi$ or CD11b+ DC [46]. More recent studies have shown that $\mathrm{m} \Phi$-derived IL-10 is important for maintaining local regulatory $\mathrm{T}$ cell differentiation in the intestine and that this is needed to prevent inflammatory reactions against commensal bacteria and food proteins $[5,13,25]$. As these $m \Phi$ cannot migrate to meet naïve CD4+ T cells in MLN in the resting condition, their role may be to maintain the survival of Treg in the mucosa. This idea has been confirmed by recent elegant studies which show that IL-10-producing CX3CR1+ $\mathrm{m} \Phi$ in the small intestinal mucosa are needed for the induction of local and systemic tolerance after feeding protein antigens [25]. In these experiments, tolerance was associated with FoxP3+ Treg whose differentiation was initiated in the MLN by antigen loaded, RA producing CD103+ DC. Having acquired gut homing markers, the Treg exited the MLN and migrated to the mucosal lamina propria where further clonal expansion and terminal differentiation occurred under control of IL-10-producing CX3CR1+ $\mathrm{m} \Phi$. This result is reminiscent of other recent work which suggests that effector $\mathrm{T}$ cell differentiation in tissues such as the skin may require two separate 'hits' from antigen and $\mathrm{APC}$, one in the draining LN and the second via DC in 
the tissue itself [47]. Resident human mucosal $m \Phi$ have been found to produce CCL20 (MIP3 $\alpha$ ) whose ligand CCR6 is expressed on FoxP3+ Treg and this may encourage local interactions between $\mathrm{m} \Phi$ and Treg in the healthy gut [48]. Interestingly both the generation of Treg and tolerance were absent in CX3CR1 KO mice, not because CX3CR1+ $\mathrm{m} \Phi$ failed to accumulate in the mucosa, but because they could not produce IL-10 once there [25]. Together these findings support a critical role for mucosal $\mathrm{m} \Phi$ in shaping local and systemic immune responses to intestinal antigens.

\section{Intestinal MФ and Their Relatives}

A number of functional $\mathrm{m} \Phi$ subsets have been described in mice, including 'classical' (M1) and 'alternatively' activated (M2) $m \Phi$ which contribute to Th1- and Th2-mediated forms of immune response, respectively, by producing distinctive patterns of mediators (table 1 ). Within the M2 population there is also a group of $\mathrm{m} \Phi$ with immunoregulatory and anti-inflammatory properties that are very similar to those of resident mucosal $\mathrm{m} \Phi$. These 'M2-like' $m \Phi$ express CD163 and CD206 lectin receptors, and produce IL-10 as well as tissue remodelling factors such as VEGF, metalloproteinases and activin. In parallel, they cannot produce pro-inflammatory mediators in response to stimulation $[49,50]$. Often found infiltrating tumours and during tissue repair, these 'M2like' cells are also usually class II MHC+ and phagocytic, underlining their similarity to mucosal $\mathrm{m} \Phi[10,50]$. Thus, $m \Phi$ in the healthy intestine may be part of a functional subset involved in the physiological processes of tissue remodelling and prevention of inflammation against commensal microbes.

\section{Mechanisms of Inertia in Mucosal MФ}

The molecular reasons underlying the functional inertia of mucosal $\mathrm{m} \Phi$ remain to be established with certainty, although a number of possibilities have been proposed. Many studies have focussed specifically on their inability to respond to TLR ligands and several reports suggested that resident intestinal $\mathrm{m} \Phi$ in both humans and mice failed to express TLR or associated receptors such as CD14 that are normally present at high levels on monocytes and $\mathrm{m} \Phi[4,8,10,21,51-53]$. However, there is now considerable evidence to suggest that these cells express many, if not all TLR both at the mRNA and pro- tein level $[10,54]$. In our hands, murine resident colon $\mathrm{m} \Phi$ express high levels of surface TLR2 protein, yet are unresponsive to stimulation via TLR2 ligands [unpubl. observations]. The position with CD14 is less clear, as most mouse intestinal $\mathrm{m} \Phi$ express high levels of this molecule, whereas human $m \Phi$ may not $[10,14]$. What is clear is that there is a functional block in signalling through the TLR receptor pathways in intestinal $\mathrm{m} \Phi$ and they fail to activate and translocate NF- $\kappa B$ p 65 to the nucleus in response to appropriate stimuli [54]. Several mechanisms have been proposed to explain these defects, including absence of a number of downstream effectors and adapters in the TLR signalling cascade, such as MyD88, IL-1 receptor-associated kinase (IRAK), IRF2, TRAF-6 and TRIF-associated adapters [54-56]. Other abnormalities that have been reported include expression of the IRAK-1 inhibitor, IRAK-M [57], and failure to express gp96. This estrogen receptor-associated chaperone is required for folding and shuttling TLR to the cell surface or endosomes $[58,59]$. Over-expression of the E3 ubiquitin-protein ligase, Triad $3 \mathrm{~A}$, which mediates degradation of some TLR has also been reported [60], as has induction of SOCS1 inhibitor of TLR signalling [54].

It is important to recognise that the functional hyporesponsiveness of intestinal $\mathrm{m} \Phi$ extends beyond TLR ligation and applies to all stimuli that have been explored. These include ligands for pattern recognition receptors such as NOD-1/NOD-2 or C-type lectins, intact bacteria or apoptotic debris, IFN- $\gamma$ and even PMA $[10,19,24]$. In addition, human intestinal $m \Phi$ lack expression of other stimulatory receptors such as FcyRI and FcyRIII, the CR3 and CR4 complement receptors [17], Fc $\alpha$ R [52] as well as the triggering receptor expressed on myeloid cells-1 (TREM-1) [26, 61]. The extensive nature of these defects makes the inertia of mucosal $\mathrm{m} \Phi$ quite distinct from the well-known phenomenon of 'endotoxin tolerance' in which exposure to a single TLR ligand suppresses subsequent responses to the same ligand. Rather, there is a profound global extinction of stimulatory potential in mucosal $\mathrm{m} \Phi$ that ensures they do not respond inappropriately to any of the potentially inflammatory constituents of their environment.

\section{Does Homeostatic Inertia of Intestinal MФ Require TLR Ligation?}

Despite the lack of overt inflammation in the intestine and the general unresponsiveness of mucosal $m \Phi$ to TLR stimulation, there is considerable evidence that their state 
of inertia may require prior TLR ligation. TLR signalling in both epithelial cells and $m \Phi$ is essential for protecting the intestinal epithelium against mechanical and toxic insults [62-64]. In addition, our recent findings suggest that there may be a low level of constitutive production of TNF- $\alpha$ by resident colonic $m \Phi$ [unpubl. observations]. It is possible that this does not go on to cause pathology because it is normally balanced by the concomitant constitutive production of IL-10 or by the effects of TGF- $\beta$ discussed above. Work on tumour-infiltrating $\mathrm{m} \Phi$ has shown that their regulatory phenotype may reflect NF$\kappa \mathrm{B}$-mediated activation of anti-inflammatory pathways due to TLR ligation in the context of special microenvironmental factors such as extracellular matrix or hypoxia [65]. However, very recent studies suggest that TLR and local bacteria may not be essential for the inertia in mu$\operatorname{cosal} \mathrm{m} \Phi$, as it can be seen in the sterile gut during foetal development, secondary to local production of TGF- $\beta$ [66]. Thus, a number of mechanisms may ensure that any pro-inflammatory responses are extinguished sufficiently rapidly to avoid damage in the normal intestine.

\section{Local Conditioning of MФ Function in the Intestine}

As the most likely origin of mucosal $\mathrm{m} \Phi$ is blood monocytes (see below) and these are fully responsive to stimulation, it is probable that factors in the intestinal environment may be responsible for 'conditioning' intestinal $\mathrm{m} \Phi$ to become unresponsive after their arrival in the gut. There are many possible candidates for this activity, but IL-10 and TGF- $\beta$ stand out. In conjunction, these cytokines can reproduce TLR or NOD-2 unresponsiveness and they down-regulate TREM-1 and CD89 expression in human blood monocytes $[61,67,68]$. As we have noted, IL-10 is produced constitutively by mucosal $\mathrm{m} \Phi$ themselves and there are also large numbers of IL-10-producing T lymphocytes in the normal intestinal mucosa [69]. IL-10 KO mice develop spontaneous IBD, as do mice in which IL-10 signalling in $\mathrm{m} \Phi$ has been abolished by targeted $\mathrm{KO}$ of Stat3 in myeloid cells [70]. Inhibiting autocrine/paracrine production of IL-10 by mucosal $\mathrm{m} \Phi$ reverses their TLR unresponsiveness in vitro [5] and the role of IL-10 is likely to reflect its ability to prevent NF- $\kappa B$ activation in $\mathrm{m} \Phi$. This may occur via inhibition of IкB kinase that normally releases NF- $\mathrm{\kappa B}$ from its inhibitory partners, or by induction of mechanisms that prevent NF- $\mathrm{B}$ binding to DNA such as the inhibitory IкB family members, IкBNS and Bcl-3 [19, 71, 72]. Clearly, IL-10 is an important physiological regulator of intestinal $\mathrm{m} \Phi$ function.
TGF- $\beta$ is a ubiquitous cytokine with many immunomodulatory and anti-inflammatory properties that are important in the intestine, including the maintenance and function of regulatory $\mathrm{T}$ cells and the switching of IgA production in naïve B lymphocytes $[73,74]$. TGF- $\beta$ is produced abundantly by many different cells in the mucosa, including haematopoietic cells, epithelial cells and mesenchymal stromal cells [10], and it plays important roles in regulating epithelial cell differentiation and renewal [75]. TGF- $\beta$ itself is a potent inducer of M2-like regulatory $\mathrm{m} \Phi$ differentiation [50] and FoxP3+ Treg can also do this in a partially TGF- $\beta$-dependent manner [76]. As we have discussed, it is now clear that $\mathrm{m} \Phi$ interact closely with Treg in the mucosa [25], and recent studies have shown that resident human mucosal $\mathrm{m} \Phi$ express high levels of TGF- $\beta$ receptors. In parallel they have constitutively active TGF- $\beta$ signalling via the Smad4 transcription factor [54]. TGF- $\beta$ itself induces the expression of inhibitory $\mathrm{I} \kappa \mathrm{B} \alpha$ in $\mathrm{m} \Phi$ and also promotes ubiquitinylation and degradation of MyD88 [76]. The inability of mucosal $\mathrm{m} \Phi$ to activate and translocate NF- $\kappa \mathrm{B}$ after TLR stimulation treatment can be reproduced in blood monocytes by treatment with TGF- $\beta$ derived from intestinal stromal cells [54]. In addition, TGF- $\beta$ from adult intestine prevents foetal intestinal $\mathrm{m} \Phi$ from responding to TLR ligation [66]. Altogether, these findings indicate that TGF- $\beta$ derived from a number of sources is likely to be key to determining $\mathrm{m} \Phi$ behaviour in the intestine and may be at the centre of a crucial two-way homeostatic interaction between $\mathrm{m} \Phi$ and Treg. Importantly, mucosa from patients with Crohn's disease shows an intrinsic resistance to TGF- $\beta$ receptor signalling, indicating how dysregulation of this pathway may be of clinicopathological significance [77].

A variety of other factors could be involved in conditioning local $\mathrm{m} \Phi$ inertia. These include mediators that have been shown to have similar effects on intestinal DC, such as RA and thymic stromal lymphopoietin [78], or agents that are produced in high quantities in the gut and that have been reported to drive anti-inflammatory $m \Phi$ in other sites, such as vasoactive intestinal peptide [79]. As noted above, CX3CL1 has been implicated in inducing IL-10 production by mucosal CX3CR $1+\mathrm{m} \Phi[25]$ and this chemokine is produced by intestinal epithelial cells in large quantities [80]. Similar conditioning effects of CX3CL1 have been shown for $m \Phi$ from other tissues such as the brain [81], but contradictory reports have also suggested that CX3CL1 may activate $m \Phi[3]$ and this issue needs to be examined more carefully. 


\section{Inhibitory Receptors and MФ Inertia}

One further possibility we have considered to explain the unresponsiveness of mucosal $\mathrm{m} \Phi$ is that there could be constitutive ligation of potentially inhibitory receptors. A candidate we considered was CD200 receptor 1 (CD200R1), an Ig superfamily molecule expressed at high levels on myeloid cells that recognises the ubiquitously expressed ligand CD200 and induces negative signalling by as yet unknown mechanisms [82]. Knock-out of CD200 or CD200R1 leads to $\mathrm{m} \Phi$ hyperactivity and autoimmune disease in vivo $[83,84]$, and recent studies have shown that deleting or inhibiting the CD200-CD200R1 interaction renders mice more susceptible to lung inflammation during infection with influenza virus [85]. This correlates with CD200R1 expression by alveolar $\mathrm{m} \Phi$, a feature which is also characteristic of $\mathrm{m} \Phi$ from resting colon (fig. 3). Together with the fact that CD200R1 can be induced by IL-10 and TGF- $\beta$ [85], this led us to hypothesise that lack of CD200R1 might also predispose to intestinal inflammation. However, preliminary results indicate that CD200R1 KO mice have normal intestinal $\mathrm{m} \Phi$ populations, do not develop spontaneous IBD and are not more susceptible to colitis induced by oral administration of DSS (fig. 3) [unpubl. observations]. Thus, CD200R1 does not appear to play an essential role in regulating intestinal $\mathrm{m} \Phi$ behaviour.

Finally, the intestine is rich in endogenous and exogenous lipid ligands for PPAR- $\gamma$, and targeted deletion of PPAR- $\gamma$ in myeloid cells under the lysozyme promoter leads to spontaneous activation of mucosal $m \Phi$ as well as increased susceptibility to experimental colitis. In turn, these pathological features can be prevented in intact mice by administration of exogenous PPAR- $\gamma$ ligands $[44,86]$. Thus, there may be several levels of local control that normally ensure down-regulation of intestinal $\mathrm{m} \Phi$ function.

\section{Intestinal MФ in Inflammation}

The phenotype and behaviour of mucosal $\mathrm{m} \Phi$ change dramatically during protective immune responses or in inflammation. Under these circumstances, there is an intense infiltration of $\mathrm{m} \Phi$ that express higher levels of TLR, CD14, co-stimulatory molecules, TREM-1 and other proinflammatory receptors than their resident counterparts $[10,18,53,87]$. These $m \Phi$ also produce large quantities of mediators such as TNF- $\alpha$, IL-1, IL- 6 , nitric oxide, reactive oxygen intermediates, cathepsins and metallopro-

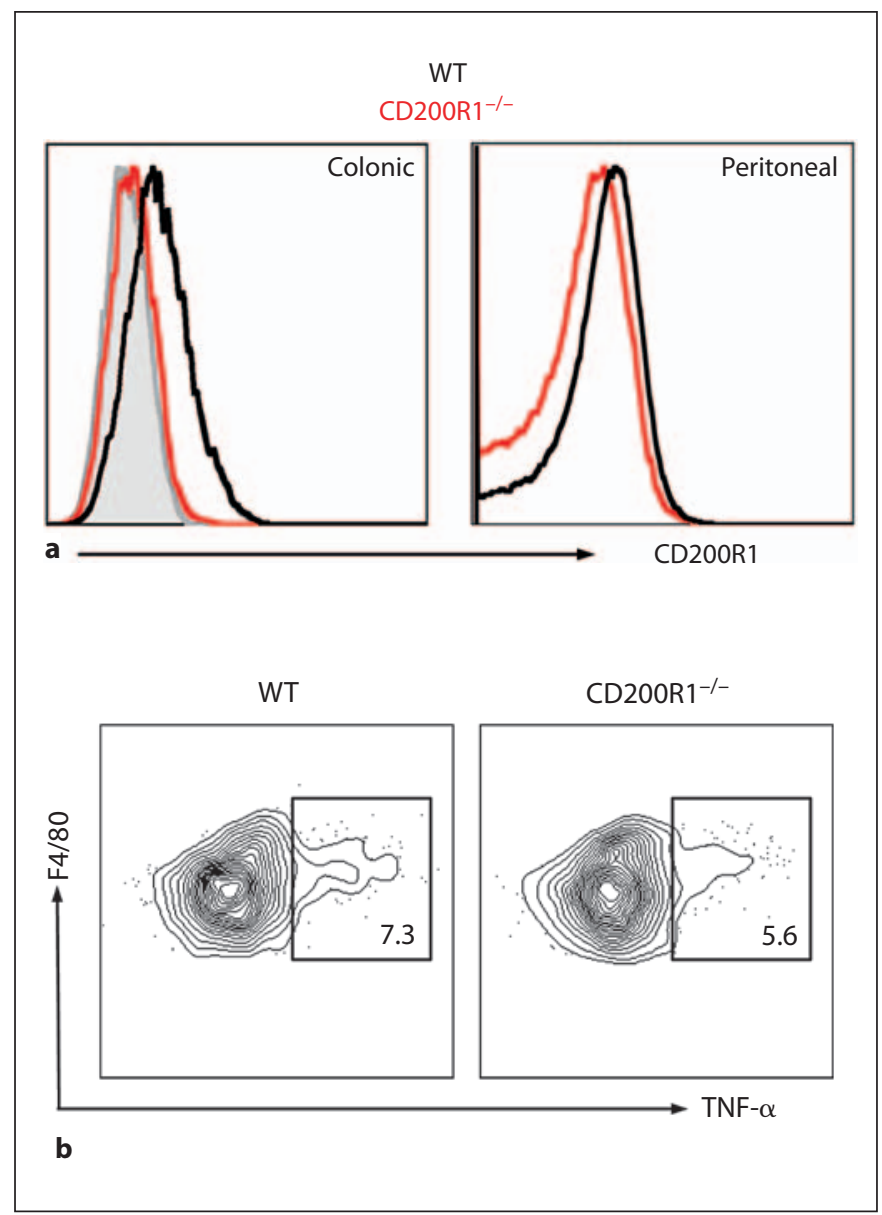

Fig. 3. CD200R1 and intestinal $m \Phi$ function. Resident colonic $\mathrm{m} \Phi$ express CD200R1 (a), but lack of CD200R1 does not affect the production of TNF- $\alpha$ by purified colonic F $4 / 80^{\text {hi }}$ class II MHC ${ }^{\text {hi }}$ $\mathrm{m} \Phi$ in response to the TLR2 ligand bacterial lipopeptide (b).

teases [20,88-91]. As a result, inflammatory $m \Phi$ play crucial roles in the pathogenesis of Crohn's disease and other forms of IBD, as well as in protection against intracellular infections such as salmonellosis, cryptosporidiosis and toxoplasmosis [10, 92-94]. The major role of mucosal $\mathrm{m} \Phi$ in protective immunity is likely to be mainly as non-specific effector cells, rather than in initiating the adaptive immune responses, as the entry of and immune responses to fully pathogenic Salmonella that normally enter via Peyer's patches do not require CX3CR1+ mucosal $\mathrm{m} \Phi$ to capture luminal bacteria [95].

An important but unresolved issue is whether the changes in $\mathrm{m} \Phi$ behaviour that occur in inflammation reflect alterations in the normally unresponsive resident population, or if there is recruitment of new, fully respon- 
sive cells (fig. 4). Currently, most evidence favours the latter idea, but it is unclear if these newly arrived $\mathrm{m} \Phi$ belong to a distinct lineage from those responsible for maintaining homeostasis in the healthy intestine.

\section{Ontogeny and Recruitment of Intestinal MФ in Inflammation}

The lack of precise markers for identifying mucosal $\mathrm{m} \Phi$ means that many studies which have attempted to examine their origins were focussed mostly on defining subsets of DC and ignored the possibility that $\mathrm{m} \Phi$ might also have been present.

Despite this proviso, it seems clear that inflammatory $\mathrm{m} \Phi$ in mouse intestine are derived from a newly recruited and recently divided population of Ly6 $\mathrm{C}^{\text {hi }}$ blood monocytes (fig. 4). This would be consistent with work in other tissues $[49,96]$ and when transferred into mice lacking all $\mathrm{m} \Phi$ and $\mathrm{DC}, \mathrm{Ly} 6 \mathrm{C}^{\mathrm{hi}}$ monocytes give rise to a population of CD11b+CD11c+ CX3CR1+ E-cadherin+ class II MHC+ $\mathrm{m} \Phi$ in the mucosa. These can produce copious amounts of TNF- $\alpha$ and other inflammatory mediators $[7,27,28,97]$.

A similar recruitment of cytokine producing monocyte-derived CD14+ $\mathrm{m} \Phi$ is seen in the lesions of active Crohn's disease in man $[21,24,51,61,88]$ and so there is considerable interest in exploiting the mechanisms responsible as targets for therapy. The Ly6 $\mathrm{C}^{\text {hi }}$ monocytes that give rise to inflammatory $\mathrm{m} \Phi$ in the mouse intestine are CCR2+ and their accumulation is dependent on this chemokine receptor in the same way as it is in other inflamed sites $[8,49]$. In parallel, increased levels of CCR2 ligands can be found in inflamed mucosa and experimental colitis in mice is abolished in CCR2 KO mice $[8,10]$. Other factors that may contribute to the recruitment of inflammatory $\mathrm{m} \Phi$ include CCR $5[98,99]$ and enhanced expression of the adhesion molecules P-selectin glycoprotein ligand-1, VCAM-1, CD31 and ICAM-1 on endothelial cells in the inflamed mucosa $[100,101]$. The progeny of Ly6 $\mathrm{C}^{\text {hi }}$ monocytes in T cell-dependent colitis in mice also express CCR6 [97], whose ligand CCL20 is present in the intestine, but it is not known if CCR6 is required for the recruitment of inflammatory $\mathrm{m} \Phi$ to the intestine. It has also been reported that mice lacking the CX3CR1 chemokine receptor have a defect in the recruitment of $\mathrm{m} \Phi$ to the inflamed colon and spleen, as well as being resistant to experimental colitis $[3,49,102]$. Thus, several different factors may play redundant and/or overlapping roles in recruiting monocytes to the inflamed gut.

\section{Ontogeny and Recruitment of Resident Intestinal M $\Phi$}

The origins of the resident population of $\mathrm{m} \Phi$ found in healthy intestine have been less easy to identify (fig. 4), but their presence is dependent on the myeloid growth factors CSF-1 and GM-CSF, and independent of the DCspecific flt3 tyrosine kinase receptor [7, 9, 27]. In mice, it is believed that a discrete population of CX3CR1+ Ly6Cmonocyte gives rise to tissue resident $\mathrm{m} \Phi$ [49]. However, the entry of such monocytes into the intestine has never been shown directly. Indeed the only study to have examined this could not find any progeny of transferred CX3CR1+ Ly6C- monocytes in the intestine, even in mice depleted of all $\mathrm{m} \Phi$ and DC [28]. As kinetic studies indicate that resident $\mathrm{CX} 3 \mathrm{CR} 1+\mathrm{m} \Phi$ turn over very slowly in vivo $[14,16]$, the entry of their precursors into the normal gut may be a relatively rare event and difficult to demonstrate experimentally. Somewhat surprisingly, inflammatory Ly6 $\mathrm{C}^{\text {hi }}$ monocytes have been shown to repopulate intestinal $\mathrm{m} \Phi$ in the absence of overt inflammation, although this can only be seen when the resident populations have been ablated for example by irradiation or diphtheria toxin-mediated depletion of CD11c+ myeloid cells $[7,27]$. One interpretation of this is that the antigenic challenge faced by the normal intestine may make it behave like an 'inflamed' tissue in terms of its $\mathrm{m} \Phi$ renewal. Certainly this would be consistent with the fact that all resident $m \Phi$ in mouse mucosa express CCR2 [26, unpubl. observations], a receptor that is normally associated specifically with the inflammatory Ly $6 \mathrm{C}^{\text {hi }}$ subset of monocyte. Although it is difficult to exclude the possibility that the conditioning regimes necessary to demonstrate entry of $\mathrm{m} \Phi$ into the otherwise healthy intestine induce mild inflammation, the entry of IL-10producing $\mathrm{m} \Phi$ into normal mouse intestine is dependent on the chemokine CCL2, one of the ligands for CCR2 [103]. Therefore, the monocytes that give rise to $\mathrm{m} \Phi$ in resting intestine may be distinct from those that replenish other tissues.

Given these issues, it is not surprising that the factors responsible for recruiting resident $\mathrm{m} \Phi$ to the healthy gut are also unclear. Although it has been shown that TGF- $\beta$ and IL- 8 produced by intestinal stromal cells may act as chemotactic factors for resting monocytes [104], the role of these factors in recruiting resident intestinal $\mathrm{m} \Phi$ in vivo has yet to be proved. Despite the high levels of expression of CX3CR1 on resident mucosal $\mathrm{m} \Phi$ and its possible role in recruiting inflammatory $\mathrm{m} \Phi$, the CX3CR1CX3CL1 axis does not seem to play an essential role in 


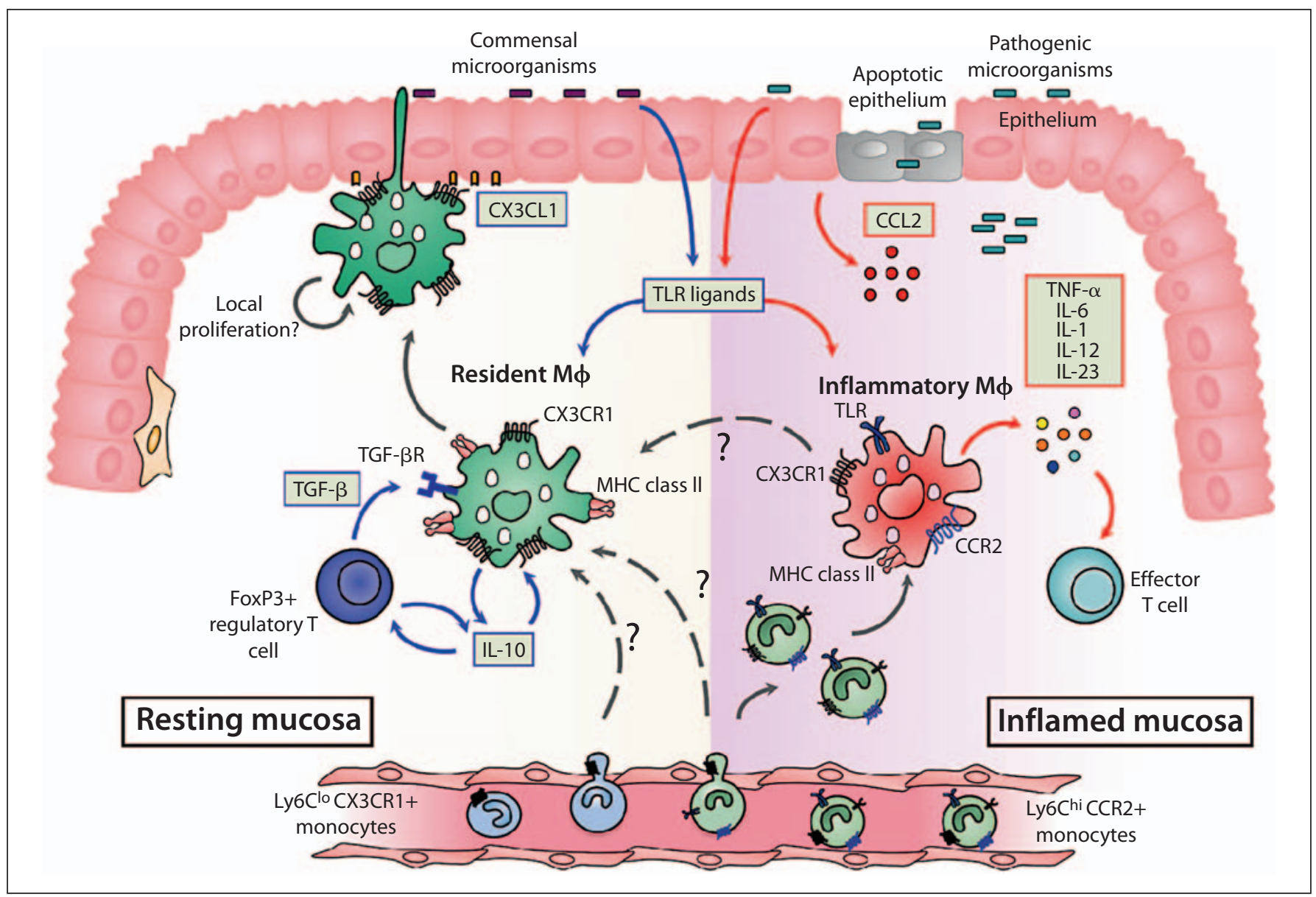

Fig. 4. Origin and diversity of intestinal $m \Phi$ in healthy and inflamed intestine. In resting intestine, the majority of intestinal $\mathrm{m} \Phi$ express high levels of $\mathrm{CX} 3 \mathrm{CR} 1$, the receptor for the transmembrane chemokine fractalkine (CX3CL1) expressed by intestinal epithelial cells. These $\mathrm{m} \Phi$ can ingest and kill commensal bacteria, perhaps by extending processes across the epithelial barrier into the lumen. They produce IL-10 constitutively, but are unable to produce pro-inflammatory mediators in response to TLR or other stimuli. This means that resident intestinal $\mathrm{m} \Phi$ cannot assist effector $\mathrm{T}$ cell activity, but instead, their production of IL-10 is needed to maintain the survival of local FoxP3+ Treg. In turn, the Treg produce TGF- $\beta$ which, together with IL-10 and other local factors, maintain resident $\mathrm{m} \Phi$ in their state of partial inertia. This may also require TLR signalling from the commensal microbiota. The resident $\mathrm{m} \Phi$ are long-lived, and may be replenished directly from the bloodstream either by resident CX3CR1+ Ly6C ${ }^{\text {lo }}$ monocytes or by inflammatory CX3CR $1^{\text {lo }}$ Ly6 $\mathrm{C}^{\text {hi }}$ monocytes. There may also be local turnover of resident $\mathrm{m} \Phi$, or differentiation of the small numbers of CX3CR $1^{\text {int }}$ inflammatory $\mathrm{m} \Phi$ present in normal mucosa (see text for details). After breach of the epithelial barrier, or pathogenic invasion, the mucosa is infiltrated by large numbers of inflammatory $\mathrm{m} \Phi$ which express lower levels of CX $3 C R 1$. These CX $3 C R 1^{\text {int }} \mathrm{m} \Phi$ are derived from recently divided inflammatory CX3CR $1^{\text {lo }}$ Ly6C ${ }^{\text {hi }}$ CCR2+ monocytes in the bloodstream, recruited in response to increased levels of CCR 2 ligands. The CX $3 C R 1^{\text {int }} \mathrm{m} \Phi$ producelarge amounts of pro-inflammatory mediators that drive local inflammation and promote the function of effector T cells. Some inflammatory CX3CR $1^{\text {int }} \mathrm{m} \Phi$ may eventually differentiate into resident $\mathrm{CX} 3 \mathrm{CR} 1^{\text {hi }} \mathrm{m} \Phi$ to assist resolution of damage. $\mathrm{m} \Phi$ recruitment to the healthy intestine, as CX3CR1 KO mice have normal populations of resident $\mathrm{m} \Phi[28,105$, unpubl. observations]. However, as noted above, CCR2 may play a counter-intuitive role in recruiting both resident and inflammatory $\mathrm{m} \Phi$ in contrast to its pro-inflammatory role in other tissues.

\section{Self-Renewal of Intestinal M $\Phi$ as a Local Mechanism of Replenishment}

One possible explanation for the difficulties in identifying the precursors of resident intestinal $\mathrm{m} \Phi$ is that they could be replenished by local self-renewal in situ 
(fig. 4). This is known to occur with some other mononuclear cell populations, including microglia in the central nervous system and Kupffer cells in the liver, as well as for the DC-related Langerhans cells in the epidermis of the skin [49, 106-108]. In these cases, the resident population is established before, or just after birth, by a myeloid precursor which subsequently self-renews. There may also be a contribution from blood-derived monocytes throughout normal adult life and, during inflammation, there is an intense recruitment of inflammatory monocytes that dilutes out the resident $\mathrm{m} \Phi$ population, as occurs in inflamed intestine [26]. The possibility that self-renewing $\mathrm{m} \Phi$ may exist in the gut has not been addressed directly, but adoptively transferred Ly6 $\mathrm{C}^{\text {hi }}$ monocytes appeared to undergo clonal expansion in villus mucosa in $\mathrm{m} \Phi / \mathrm{DC}$-depleted recipients [28]. In addition, mucosal $\mathrm{m} \Phi$ are absent in CSF-1 receptor KO mice and after antibody-mediated neutralisation of CSF-1R [9, 27], despite the fact that blood monocytes can repopulate other tissue $\mathrm{m} \Phi$ in CSF-1R KO mice [108]. Thus, the need for CSF-1 may be in maturation of local precursors [9], and if these findings can be confirmed in physiological conditions, they would suggest that self-renewal of $\mathrm{m} \Phi$ might be an important process in the healthy intestine.

\section{CX3CR1 Expression as a Marker of Resident and Inflammatory $M \Phi$ in the Intestine}

One of the reasons so little is known about the origins and recruitment of resident and inflammatory $m \Phi$ in the intestine has been the lack of precise phenotypic markers with which to distinguish these cells. Very recent work may provide some novel insights into this, by showing that two distinct subsets of inflammatory and resident $\mathrm{m} \Phi$ can be identified in the intestine on the basis of their level of CX3CR1 expression [26, unpubl. observations]. In the resting state, the majority of mucosal $\mathrm{m} \Phi$ express levels of CX3CR1 that are higher than any other myeloid population (fig. 2), and this resident subset expresses mRNA for anti-inflammatory factors such as IL-10, Homxl and the mannose receptor; it is also unresponsive to stimulation in vitro [26]. The 'inert' status of these $\mathrm{CX} 3 \mathrm{CR} 1^{\text {hi }} \mathrm{m} \Phi$ changes little during inflammation, when they are diluted out by a TLR-responsive population which expresses lower levels of CX3CR1, as well as producing TNF- $\alpha$ and other inflammatory mediators such as IL-6 and iNOS [26]. Both subsets are CD11b ${ }^{\text {hi }}$ F4/80+ class II MHC+ and are heterogeneous for CD11c expres- sion, meaning they cannot be distinguished on the basis of these conventional markers. Interestingly, a small number of these CX $3 C R 1^{\text {int }} \mathrm{m} \Phi$ is also found in the normal intestine and it is tempting to speculate that it is these active cells which account for the homeostatic functions of $\mathrm{m} \Phi$ in the healthy gut.

\section{Conclusions}

$M \Phi$ are a fundamental component of the innate immune system in the healthy and inflamed intestine, where they play essential roles in homeostasis and disease. In normal gut, they are held in a state of partial inertia, but this changes rapidly during inflammation, by as yet unknown mechanisms. Although mucosal $m \Phi$ are now clearly heterogeneous in nature, it is not known whether inflammation reflects plasticity within individual subsets or is due to changes in the balance of their recruitment. Importantly, although inflammatory $\mathrm{m} \Phi$ seem to be derived from Ly $6 \mathrm{C}^{\text {hi }}$ monocytes, the precursor of resident intestinal $\mathrm{m} \Phi$ has not been identified directly. Whether this is the CX3CR1+ 'resident' monocyte, whether they are generated from local conditioning of initially inflammatory $\mathrm{m} \Phi$ or whether they are maintained by local turnover and renewal, as can occur with some $\mathrm{m} \Phi$ in other tissues are important questions for future work. These crucial studies will inform the specificity and safety of new therapeutic strategies aimed at targeting the recruitment and/or activation of one or other of the $m \Phi$ subsets.

\section{Acknowledgements}

The authors are grateful to Drs Bill Agace and Oliver Pabst for fruitful discussions of the topic. The work of the authors quoted was supported by the Wellcome Trust and the Medical Research Council, UK. 


\section{References}

1 Hume DA: The mononuclear phagocyte system. Curr Opin Immunol 2006;18:49-53.

$\checkmark 2$ Lee SH, Starkey PM, Gordon S: Quantitative analysis of total macrophage content in adult mouse tissues. Immunochemical studies with monoclonal antibody F4/80. J Exp Med 1985; 161:475-489.

$\checkmark 3$ Niess JH, Adler G: Enteric flora expands gut lamina propria CX3CR1+ dendritic cells supporting inflammatory immune responses under normal and inflammatory conditions. J Immunol 2010;184:2026-2037.

$>4$ Rogler G, Hausmann M, Vogl D, Aschenbrenner E, Andus T, Falk W, Andreesen R, Scholmerich J, Gross V: Isolation and phenotypic characterization of colonic macrophages. Clin Exp Immunol 1998;112:205215.

$\checkmark 5$ Denning TL, Wang YC, Patel SR, Williams IR, Pulendran B: Lamina propria macrophages and dendritic cells differentially induce regulatory and interleukin 17-producing $\mathrm{T}$ cell responses. Nat Immunol 2007;8: 1086-1094.

-6 Smith P, Mangan NE, Walsh CM, Fallon RE, McKenzie AN, van Rooijen N, Fallon PG: Infection with a helminth parasite prevents experimental colitis via a macrophage-mediated mechanism. J Immunol 2007;178:45574566.

$>7$ Varol C, Zigmond E, Jung S: Securing the immune tightrope: mononuclear phagocytes in the intestinal lamina propria. Nat Rev Immunol 2010;10:415-426.

$>8$ Platt AM, Bain CC, Bordon Y, Sester DP, Mowat AM: An independent subset of TLR expressing CCR2-dependent macrophages promotes colonic inflammation. J Immunol 2010;184:6843-6854.

$\checkmark 9$ MacDonald KP, Palmer JS, Cronau S, Seppanen E, Olver S, Raffelt NC, Kuns R, Pettit AR, Clouston A, Wainwright B, Branstetter D, Smith J, Paxton RJ, Cerretti DP, Bonham L, Hill GR, Hume DA: An antibody against the colony-stimulating factor 1 receptor depletes the resident subset of monocytes and tissue- and tumor-associated macrophages but does not inhibit inflammation. Blood 2010;116:3955-3963.

10 Smith PD, Smythies LE, Shen R, GreenwellWild T, Gliozzi M, Wahl SM: Intestinal macrophages and response to microbial encroachment. Mucosal Immunol 2011;4:31-42.

-11 Uematsu S, Jang MH, Chevrier N, Guo Z, Kumagai Y, Yamamoto M, Kato H, Sougawa N, Matsui H, Kuwata H, Hemmi H, Coban C, Kawai T, Ishii KJ, Takeuchi O, Miyasaka M, Takeda K, Akira S: Detection of pathogenic intestinal bacteria by Toll-like receptor 5 on intestinal CD11c+ lamina propria cells. Nat Immunol 2006;7:868-874.

$\checkmark 12$ Hume DA: Differentiation and heterogeneity in the mononuclear phagocyte system. Mucosal Immunol 2008;1:432-441.
13 Murai M, Turovskaya O, Kim G, Madan R, Karp CL, Cheroutre H, Kronenberg M: Interleukin 10 acts on regulatory $\mathrm{T}$ cells to maintain expression of the transcription factor Foxp3 and suppressive function in mice with colitis. Nat Immunol 2009;10:1178-1184.

14 Schulz O, Jaensson E, Persson EK, Liu X, Worbs T, Agace WW, Pabst O: Intestinal CD103+, but not CX3CR1+, antigen sampling cells migrate in lymph and serve classical dendritic cell functions. J Exp Med 2009;206:3101-3114.

15 Geissmann F, Gordon S, Hume DA, Mowat AMcI, Randolph GJ: Unravelling mononuclear phagocyte heterogeneity. Nat Rev Immunol 2010;10:453-460.

16 Persson EK, Jaensson E, Agace WW: The diverse ontogeny and function of murine small intestinal dendritic cell/macrophage subsets. Immunobiology 2010;215:692-697.

17 Smythies LE, Sellers M, Clements RH, Mosteller-Barnum M, Meng G, Benjamin WH, Orenstein JM, Smith PD: Human intestinal macrophages display profound inflammatory anergy despite avid phagocytic and bacteriocidal activity. J Clin Invest 2005;115:66-75.

18 Carlsen HS, Yamanaka T, Scott H, Rugtveit J, Brandtzaeg P: The proportion of CD40+ mucosal macrophages is increased in inflammatory bowel disease whereas CD40 ligand $(\mathrm{CD} 154)+\mathrm{T}$ cells are relatively decreased, suggesting differential modulation of these costimulatory molecules in human gut lamina propria. Inflamm Bowel Dis 2006;12:1013-1024.

19 Hirotani T, Lee PY, Kuwata H, Yamamoto M, Matsumoto M, Kawase I, Akira S, Takeda K: The nuclear IкB protein IкBNS selectively inhibits lipopolysaccharide-induced IL-6 production in macrophages of the colonic lamina propria. J Immunol 2005;174:36503657.

20 Mahida YR, Wu KC, Jewell DP: Respiratory burst activity of intestinal macrophages in normal and inflammatory bowel disease. Gut 1989;30:1362-1370.

21 Rugtveit J, Haraldsen G, Hogasen AK, Bakka A, Brandtzaeg P, Scott H: Respiratory burst of intestinal macrophages in inflammatory bowel disease is mainly caused by CD14+L1+ monocyte derived cells. Gut 1995;37:367373.

-22 Ikeda I, Kasajima T, Ishiyama S, Shimojo T, Takeo Y, Nishikawa T, Kameoka S, Hiroe M, Mitsunaga A: Distribution of inducible nitric oxide synthase in ulcerative colitis. Am J Gastroenterol 1997;92:1339-1341.

23 Roberts PJ, Riley GP, Morgan K, Miller R, Hunter JO, Middleton SJ: The physiological expression of inducible nitric oxide synthase (iNOS) in the human colon. J Clin Path 2001; 54:293-297.
24 Kamada N, Hisamatsu T, Okamoto S, Sato T, Matsuoka K, Arai K, Nakai T, Hasegawa A, Inoue N, Watanabe N, Akagawa KS, Hibi T: Abnormally differentiated subsets of intestinal macrophage play a key role in Th1-dominant chronic colitis through excess production of IL-12 and IL-23 in response to bacteria. J Immunol 2005;175:6900-6908.

25 Hadis U, Wahl B, Schulz O, Hardtke-Wolenski M, Schippers A, Wagner N, Muller W, Sparwasser T, Forster R, Pabst O: Intestinal tolerance requires gut homing and expansion of FoxP3 + regulatory T cells in the lamina propria. Immunity 2011;34:237-246.

-26 Weber B, Saurer L, Schenk M, Dickgreber N, Mueller C: CX3CR1 defines functionally distinct intestinal mononuclear phagocyte subsets which maintain their respective functions during homeostatic and inflammatory conditions. Eur J Immunol 2011;41: 773-779.

27 Bogunovic M, Ginhoux F, Helft J, Shang L, Hashimoto D, Greter M, Liu K, Jakubzick C, Ingersoll MA, Leboeuf M, Stanley ER, Nussenzweig M, Lira SA, Randolph GJ, Merad $\mathrm{M}$ : Origin of the lamina propria dendritic cell network. Immunity 2009;31:513-525.

28 Varol C, Vallon-Eberhard A, Elinav E, Aychek T, Shapira Y, Luche H, Fehling HJ, Hardt WD, Shakhar G, Jung S: Intestinal lamina propria dendritic cell subsets have different origin and functions. Immunity 2009;31:502-512.

$>29$ Arques JL, Hautefort I, Ivory K, Bertelli E, Regoli M, Clare S, Hinton JC, Nicoletti C: Salmonella induces flagellin- and MyD88dependent migration of bacteria-capturing dendritic cells into the gut lumen. Gastroenterology 2009;137:579-587, 587e1-587e2.

30 Kaser A, Zeissig S, Blumberg RS: Inflammatory bowel disease. Annu Rev Immunol 2010;28:573-621.

31 Strober W, Kitani A, Fuss I, Asano N, Watanabe T: The molecular basis of NOD2 susceptibility mutations in Crohn's disease. Mucosal Immunol 2008;1(suppl 1):S5-S9.

32 Hugot JP, Chamaillard M, Zouali H, Lesage S, Cezard JP, Belaiche J, Almer S, Tysk C, O'Morain CA, Gassull M, Binder V, Finkel Y, Cortot A, Modigliani R, Laurent-Puig P, Gower-Rousseau C, Macry J, Colombel JF, Sahbatou M, Thomas G: Association of NOD2 leucine-rich repeat variants with susceptibility to Crohn's disease. Nature 2001; 411:599-603.

33 Hampe J, Franke A, Rosenstiel P, Till A, Teuber M, Huse K, Albrecht M, Mayr G, De La Vega FM, Briggs J, Gunther S, Prescott NJ, Onnie CM, Hasler R, Sipos B, Folsch UR, Lengauer T, Platzer M, Mathew CG, Krawczak M, Schreiber S: A genome-wide association scan of nonsynonymous SNPs identifies a susceptibility variant for Crohn disease in ATG16L1. Nat Genet 2007;39:207-211. 
\$34 Rioux JD, Xavier RJ, Taylor KD, Silverberg MS, Goyette P, Huett A, Green T, Kuballa P, Barmada MM, Datta LW, Shugart YY, Griffiths AM, Targan SR, Ippoliti AF, Bernard EJ, Mei L, Nicolae DL, Regueiro M, Schumm LP, Steinhart AH, Rotter JI, Duerr RH, Cho JH, Daly MJ, Brant SR: Genomewide association study identifies new susceptibility loci for Crohn disease and implicates autophagy in disease pathogenesis. Nat Genet 2007;39:596-604.

- 35 Saitoh T, Fujita N, Jang MH, Uematsu S, Yang BG, Satoh T, Omori H, Noda T, Yamamoto N, Komatsu M, Tanaka K, Kawai T, Tsujimura T, Takeuchi O, Yoshimori T, Akira S: Loss of the autophagy protein Atg16L1 enhances endotoxin-induced IL-1beta production. Nature 2008;456:264-268.

-36 Deretic V: Autophagy in immunity and cellautonomous defense against intracellular microbes. Immunol Rev 2011;240:92-104.

- 37 Massey DC, Parkes M: Genome-wide association scanning highlights two autophagy genes, ATG16L1 and IRGM, as being significantly associated with Crohn's disease. Autophagy 2007;3:649-651.

- 38 Parkes M, Barrett JC, Prescott NJ, Tremelling $\mathrm{M}$, Anderson CA, Fisher SA, Roberts RG, Nimmo ER, Cummings FR, Soars D, Drummond $\mathrm{H}$, Lees CW, Khawaja SA, Bagnall R, Burke DA, Todhunter CE, Ahmad T, Onnie CM, McArdle W, Strachan D, Bethel G, Bryan C, Lewis CM, Deloukas P, Forbes A, Sanderson J, Jewell DP, Satsangi J, Mansfield JC, Cardon L, Mathew CG: Sequence variants in the autophagy gene IRGM and multiple other replicating loci contribute to Crohn's disease susceptibility. Nat Genet 2007;39:830-832.

39 Qualls JE, Kaplan AM, van Rooijen N, Cohen DA: Suppression of experimental colitis by intestinal mononuclear phagocytes. J Leukoc Biol 2006;80:802-815.

40 Ghia JE, Galeazzi F, Ford DC, Hogaboam $\mathrm{CM}$, Vallance BA, Collins S: Role of M-CSFdependent macrophages in colitis is driven by the nature of the inflammatory stimulus. Am J Physiol Gastrointest Liver Physiol 2008;294:G770-G777.

41 Pull SL, Doherty JM, Mills JC, Gordon JI, Stappenbeck TS: Activated macrophages are an adaptive element of the colonic epithelial progenitor niche necessary for regenerative responses to injury. Proc Natl Acad Sci USA 2005;102:99-104

42 Watanabe J, Lin JA, Narasimha AJ, Shahbazian A, Ishikawa TO, Martin MG, Herschman HR, Reddy ST: Novel anti-inflammatory functions for endothelial and myeloid cyclooxygenase- 2 in a new mouse model of Crohn's disease. Am J Physiol Gastrointest Liver Physiol 2010;298:G842-G850.

43 Jiang C, Ting AT, Seed B: PPAR-gamma agonists inhibit production of monocyte inflammatory cytokines. Nature 1998;391:8286.
44 Shah YM, Morimura K, Gonzalez FJ: Expression of peroxisome proliferator-activated receptor-gamma in macrophage suppresses experimentally induced colitis. Am J Physiol Gastrointest Liver Physiol 2007; 292:G657-G666.

45 Lin HH, Faunce DE, Stacey M, Terajewicz A, Nakamura T, Zhang-Hoover J, Kerley M, Mucenski ML, Gordon S, Stein-Streilein J: The macrophage $\mathrm{F} 4 / 80$ receptor is required for the induction of antigen-specific efferent regulatory $\mathrm{T}$ cells in peripheral tolerance. $\mathrm{J}$ Exp Med 2005;201:1615-1625.

46 Ehirchiou D, Xiong Y, Xu G, Chen W, Shi Y, Zhang L: CD11b facilitates the development of peripheral tolerance by suppressing Th17 differentiation. J Exp Med 2007;204:15191524.

47 McLachlan JB, Catron DM, Moon JJ, Jenkins MK: Dendritic cell antigen presentation drives simultaneous cytokine production by effector and regulatory $\mathrm{T}$ cells in inflamed skin. Immunity 2009;30:277-288.

48 Hausmann M, Bataille F, Spoettl T, Schreiter K, Falk W, Schoelmerich J, Herfarth H, Rogler G: Physiological role of macrophage inflammatory protein-3 $\alpha$ induction during maturation of intestinal macrophages. J Immunol 2005;175:1389-1398.

49 Geissmann F, Manz MG, Jung S, Sieweke MH, Merad M, Ley K: Development of monocytes, macrophages, and dendritic cells. Science 2010;327:656-661.

50 Biswas SK, Mantovani A: Macrophage plasticity and interaction with lymphocyte subsets: cancer as a paradigm. Nat Immunol 2010;11:889-896.

-51 Grimm MC, Pavli P, Van de Pol E, Doe WF: Evidence for a CD14+ population of monocytes in inflammatory bowel disease mucosa - implications for pathogenesis. Clin Exp Immunol 1995;100:291-297.

52 Smith PD, Smythies LE, Mosteller-Barnum M, Sibley DA, Russell MW, Merger M, Sellers MT, Orenstein JM, Shimada T, Graham MF, Kubagawa $\mathrm{H}$ : Intestinal macrophages lack CD14 and CD89 and consequently are downregulated for LPS- and IgA-mediated activities. J Immunol 2001;167:2651-2656.

53 Hausmann M, Kiessling S, Mestermann S, Webb G, Spottl T, Andus T, Scholmerich J, Herfarth H, Ray K, Falk W, Rogler G: Tolllike receptors 2 and 4 are up-regulated during intestinal inflammation. Gastroenterology 2002;122:1987-2000.

54 Smythies LE, Shen R, Bimczok D, Novak L, Clements RH, Eckhoff DE, Bouchard P, George MD, Hu WK, Dandekar S, Smith PD: Inflammation anergy in human intestinal macrophages is due to Smad-induced I $\mathrm{B} \alpha$ expression and NF- $\kappa \mathrm{B}$ inactivation. J Biol Chem 2010;285:19593-19604.
55 Medvedev AE, Lentschat A, Wahl LM, Golenbock DT, Vogel SN: Dysregulation of LPS-induced Toll-like receptor 4-MyD88 complex formation and IL-1 receptor-associated kinase 1 activation in endotoxin-tolerant cells. J Immunol 2002;169:5209-5216.

56 Adib-Conquy M, Cavaillon JM: Gamma interferon and granulocyte/monocyte colonystimulating factor prevent endotoxin tolerance in human monocytes by promoting interleukin-1 receptor-associated kinase expression and its association to MyD88 and not by modulating TLR4 expression. J Biol Chem 2002;277:27927-27934.

57 Hedl M, Li J, Cho JH, Abraham C: Chronic stimulation of Nod2 mediates tolerance to bacterial products. Proc Natl Acad Sci USA 2007;104:19440-19445.

-58 Schreiter K, Hausmann M, Spoettl T, Strauch UG, Bataille F, Schoelmerich J, Herfarth H, Falk W, Rogler G: Glycoprotein (gp) 96 expression: induced during differentiation of intestinal macrophages but impaired in Crohn's disease. Gut 2005;54:935-943.

59 Yang Y, Liu B, Dai J, Srivastava PK, Zammit DJ, Lefrancois L, Li Z: Heat shock protein gp96 is a master chaperone for toll-like receptors and is important in the innate function of macrophages. Immunity 2007;26: 215-226.

60 Chuang TH, Ulevitch RJ: Triad3A, an E3 ubiquitin-protein ligase regulating Toll-like receptors. Nat Immunol 2004;5:495-502.

-61 Schenk M, Bouchon A, Seibold F, Mueller C: TREM-1-expressing intestinal macrophages crucially amplify chronic inflammation in experimental colitis and inflammatory bowel diseases. J Clin Invest 2007;117:3097-3106.

-62 Katakura K, Lee J, Rachmilewitz D, Li G, Eckmann L, Raz E: Toll-like receptor 9-induced type I IFN protects mice from experimental colitis. J Clin Invest 2005;115:695-702.

63 Rakoff-Nahoum S, Hao L, Medzhitov R: Role of Toll-like receptors in spontaneous commensal-dependent colitis. Immunity 2006; 25:319-329.

64 Rakoff-Nahoum S, Paglino J, Eslami-Varzaneh F, Edberg S, Medzhitov R: Recognition of commensal microflora by Toll-like receptors is required for intestinal homeostasis. Cell 2004;118:229-241.

65 Lawrence T: Macrophages and NF-кB in Cancer. Curr Top Microbiol Immunol 2010.

- 66 Maheshwari A, Kelly DR, Nicola T, Ambalavanan N, Jain SK, Murphy-Ullrich J, Athar M, Shimamura M, Bhandari V, Aprahamian C, Dimmitt RA, Serra R, Ohls RK: TGF- $\beta 2$ suppresses macrophage cytokine production and mucosal inflammatory responses in the developing intestine. Gastroenterology 2011; 140:242-253

67 Randow F, Syrbe U, Meisel C, Krausch D, Zuckermann H, Platzer C, Volk HD: Mechanism of endotoxin desensitization: involvement of interleukin 10 and transforming growth factor $\beta$. J Exp Med 1995;181:18871892. 
68 Hedl M, Abraham C: Secretory mediators regulate Nod2-induced tolerance in human macrophages. Gastroenterology 2011;140: 231-241.

69 Kamanaka M, Kim ST, Wan YY, Sutterwala FS, Lara-Tejero M, Galan JE, Harhaj E, Flavell RA: Expression of interleukin-10 in intestinal lymphocytes detected by an interleukin-10 reporter knockin tiger mouse. Immunity 2006;25:941-952.

-70 Takeda K, Clausen BE, Kaisho T, Tsujimura T, Terada N, Forster I, Akira S: Enhanced Th1 activity and development of chronic enterocolitis in mice devoid of Stat3 in macrophages and neutrophils. Immunity 1999;10: 39-49.

-71 Schottelius AJ, Mayo MW, Sartor RB, Baldwin AS Jr: Interleukin-10 signaling blocks inhibitor of $\kappa \mathrm{B}$ kinase activity and nuclear factor $\kappa$ B DNA binding. J Biol Chem 1999; 274:31868-31874.

72 Kuwata H, Watanabe Y, Miyoshi H, Yamamoto M, Kaisho T, Takeda K, Akira S: IL-10inducible $\mathrm{Bcl}-3$ negatively regulates LPS-induced TNF- $\alpha$ production in macrophages. Blood 2003;102:4123-4129.

73 Cerutti A, Rescigno M: The biology of intestinal immunoglobulin A responses. Immunity 2008;28:740-750.

-74 Izcue A, Coombes JL, Powrie F: Regulatory lymphocytes and intestinal inflammation. Annu Rev Immunol 2009;27:313-338.

75 Dignass AU, Podolsky DK: Cytokine modulation of intestinal epithelial cell restitution: central role of transforming growth factor $\beta$. Gastroenterology 1993;105:1323-1332.

-76 Liu G, Ma H, Qiu L, Li L, Cao Y, Ma J, Zhao Y: Phenotypic and functional switch of macrophages induced by regulatory CD4+CD25+ T cells in mice. Immunol Cell Biol 2011;89:130-142.

77 Monteleone G, Boirivant M, Pallone F, MacDonald TT: TGF- $\beta 1$ and Smad7 in the regulation of IBD. Mucosal Immunol 2008;1 (suppl 1):S50-S53.

-78 Rescigno M: Intestinal dendritic cells. Adv Immunol 2010;107:109-138.

-79 Delgado M, Ganea D: Inhibition of endotoxin-induced macrophage chemokine production by vasoactive intestinal peptide and pituitary adenylate cyclase-activating polypeptide in vitro and in vivo. J Immunol 2001; 167:966-975.

80 Lucas AD, Chadwick N, Warren BF, Jewell DP, Gordon S, Powrie F, Greaves DR: The transmembrane form of the CX3CL1 chemokine fractalkine is expressed predominantly by epithelial cells in vivo. Am J Pathol 2001;158:855-866.

-81 Lyons A, Lynch AM, Downer EJ, Hanley R, O'Sullivan JB, Smith A, Lynch MA: Fractalkine-induced activation of the phosphatidylinositol-3 kinase pathway attentuates microglial activation in vivo and in vitro. J Neurochem 2009;110:1547-1556.
82 Mihrshahi R, Barclay AN, Brown MH: Essential roles for Dok2 and RasGAP in CD200 receptor-mediated regulation of human myeloid cells. J Immunol 2009;183:4879-4886.

83 Wright GJ, Puklavec MJ, Willis AC, Hoek RM, Sedgwick JD, Brown MH, Barclay AN: Lymphoid/neuronal cell surface OX2 glycoprotein recognizes a novel receptor on macrophages implicated in the control of their function. Immunity 2000;13:233-242.

84 Boudakov I, Liu J, Fan N, Gulay P, Wong K, Gorczynski RM: Mice lacking CD200R1 show absence of suppression of lipopolysaccharide-induced tumor necrosis factor- $\alpha$ and mixed leukocyte culture responses by CD200. Transplantation 2007;84:251-257.

85 Snelgrove RJ, Goulding J, Didierlaurent AM, Lyonga D, Vekaria S, Edwards L, Gwyer E, Sedgwick JD, Barclay AN, Hussell T: A critical function for CD200 in lung immune homeostasis and the severity of influenza infection. Nat Immunol 2008;9:1074-1083.

86 Hontecillas R, Horne WT, Climent M, Guri AJ, Evans C, Zhang Y, Sobral BW, Bassaganya-Riera J: Immunoregulatory mechanisms of macrophage PPAR- $\gamma$ in mice with experimental inflammatory bowel disease. Mucosal Immunol 2011;4:304-313.

87 Rugtveit J, Bakka A, Brandtzaeg P: Differential distribution of B7.1 (CD80) and B7.2 (CD86) costimulatory molecules on mucosal macrophage subsets in human inflammatory bowel disease (IBD). Clin Exp Immunol 1997;110:104-113.

88 Rugtveit J, Nilsen EM, Bakka A, Carlsen H, Brandtzaeg P, Scott H: Cytokine profiles differ in newly recruited and resident subsets of mucosal macrophages from inflammatory bowel disease. Gastroenterology 1997;112: 1493-1505.

- 89 Rogler G, Brand K, Vogl D, Page S, Hofmeister R, Andus T, Knuechel R, Baeuerle PA, Scholmerich J, Gross V: Nuclear factor $\kappa \mathrm{B}$ is activated in macrophages and epithelial cells of inflamed intestinal mucosa. Gastroenterology 1998;115:357-369.

90 Hausmann M, Spottl T, Andus T, Rothe G, Falk W, Scholmerich J, Herfarth H, Rogler G: Subtractive screening reveals up-regulation of NADPH oxidase expression in Crohn's disease intestinal macrophages. Clin Exp Immunol 2001;125:48-55.

91 Hausmann M, Obermeier F, Schreiter K, Spottl T, Falk W, Scholmerich J, Herfarth H, Saftig P, Rogler G: Cathepsin D is up-regulated in inflammatory bowel disease macrophages. Clin Exp Immunol 2004;136:157-167.

92 Rhee SJ, Walker WA, Cherayil BJ: Developmentally regulated intestinal expression of IFN- $\gamma$ and its target genes and the age-specific response to enteric Salmonella infection. J Immunol 2005;175:1127-1136.
-93 Takeuchi D, Jones VC, Kobayashi M, Suzuki F: Cooperative role of macrophages and neutrophils in host Antiprotozoan resistance in mice acutely infected with Cryptosporidium parvum. Infect Immun 2008;76: 3657-3663.

94 Dunay IR, Fuchs A, Sibley LD: Inflammatory monocytes but not neutrophils are necessary to control infection with Toxoplasma gondii in mice. Infect Immun 2010; 78:1564-1570.

-95 Hapfelmeier S, Muller AJ, Stecher B, Kaiser P, Barthel M, Endt K, Eberhard M, Robbiani R, Jacobi CA, Heikenwalder M, Kirschning C, Jung S, Stallmach T, Kremer M, Hardt WD: Microbe sampling by mucosal dendritic cells is a discrete, MyD88-independent step in $\Delta$ invG S. typhimurium colitis. J Exp Med 2008;205:437-450.

-96 Dunay IR, Damatta RA, Fux B, Presti R, Greco S, Colonna M, Sibley LD: Grl(+) inflammatory monocytes are required for mucosal resistance to the pathogen Toxoplasma gondii. Immunity 2008;29:306-317.

$\$ 97$ Siddiqui KR, Laffont S, Powrie F: E-cadherin marks a subset of inflammatory dendritic cells that promote $\mathrm{T}$ cell-mediated colitis. Immunity 2010;32:557-567.

98 Andres PG, Beck PL, Mizoguchi E, Mizoguchi A, Bhan AK, Dawson T, Kuziel WA, Maeda N, MacDermott RP, Podolsky DK, Reinecker HC: Mice with a selective deletion of the CC chemokine receptors 5 or 2 are protected from dextran sodium sulfatemediated colitis: lack of CC chemokine receptor 5 expression results in a NK1.1+lymphocyte-associated Th2-type immune response in the intestine. J Immunol 2000; 164:6303-6312.

99 Tokuyama H, Ueha S, Kurachi M, Matsushima K, Moriyasu F, Blumberg RS, Kakimi $\mathrm{K}$ : The simultaneous blockade of chemokine receptors CCR2, CCR 5 and CXCR 3 by a non-peptide chemokine receptor antagonist protects mice from dextran sodium sulfate-mediated colitis. Int Immunol 2005; 17:1023-1034.

100 Burgio VL, Fais S, Boirivant M, Perrone A, Pallone F: Peripheral monocyte and naive T-cell recruitment and activation in Crohn's disease. Gastroenterology 1995; 109:1029-1038.

101 Inoue T, Tsuzuki Y, Matsuzaki K, Matsunaga $H$, Miyazaki J, Hokari R, Okada Y, Kawaguchi A, Nagao S, Itoh K, Matsumoto S, Miura S: Blockade of PSGL-1 attenuates CD14+ monocytic cell recruitment in intestinal mucosa and ameliorates ileitis in SAMP1/Yit mice. J Leukoc Biol 2005;77: 287-295.

102 Kostadinova FI, Baba T, Ishida Y, Kondo T, Popivanova BK, Mukaida N: Crucial involvement of the CX3CR1-CX3CL1 axis in dextran sulfate sodium-mediated acute colitis in mice. J Leukoc Biol 2010. 
103 Takada Y, Hisamatsu T, Kamada N, Kitazume MT, Honda H, Oshima Y, Saito R, Takayama T, Kobayashi T, Chinen H, Mikami Y, Kanai T, Okamoto S, Hibi T: Monocyte chemoattractant protein-1 contributes to gut homeostasis and intestinal inflammation by composition of IL-10-producing regulatory macrophage subset. J Immunol 2010;184:2671-2676.

104 Smythies LE, Maheshwari A, Clements R, Eckhoff D, Novak L, Vu HL, Mosteller-Barnum LM, Sellers M, Smith PD: Mucosal IL- 8 and TGF- $\beta$ recruit blood monocytes: evidence for cross-talk between the lamina propria stroma and myeloid cells. J Leukoc Biol 2006;80:492-499.
105 Bar-On L, Zigmond E, Jung S: Management of gut inflammation through the manipulation of intestinal dendritic cells and macrophages? Sem Immunol 2011;23:5684.

106 Ajami B, Bennett JL, Krieger C, Tetzlaff W, Rossi FM: Local self-renewal can sustain CNS microglia maintenance and function throughout adult life. Nat Neurosci 2007; 10:1538-1543.

107 Chorro L, Sarde A, Li M, Woollard KJ, Chambon P, Malissen B, Kissenpfennig A, Barbaroux JB, Groves R, Geissmann F: Langerhans cell (LC) proliferation mediates neonatal development, homeostasis, and inflammation-associated expansion of the epidermal LC network. J Exp Med 2009; 206:3089-3100.
108 Ginhoux F, Greter M, Leboeuf M, Nandi S, See P, Gokhan S, Mehler MF, Conway SJ, Ng LG, Stanley ER, Samokhvalov IM, Merad M: Fate mapping analysis reveals that adult microglia derive from primitive macrophages. Science 2010;330:841845 .

109 Stevceva L, Pavli P, Husband AJ, Doe WF: The inflammatory infiltrate in the acute stage of the dextran sulphate sodium induced colitis: B cell response differs depending on the percentage of DSS used to induce it. BMC Clin Pathol 2001;1:3. 